\title{
Behaviour and passage success of upriver-migrating lake sturgeon Acipenser fulvescens in a vertical slot fishway on the Richelieu River, Quebec, Canada
}

\author{
J. D. Thiem ${ }^{1, *}$, T. R. Binder ${ }^{1}$, J. W. Dawson ${ }^{2}$, P. Dumont ${ }^{3}$, D. Hatin ${ }^{3}$, C. Katopodis ${ }^{4}$, \\ D. Z. $\mathrm{Zhu}^{5}$, S. J. Cooke $\mathrm{C}^{1,6}$ \\ ${ }^{1}$ Fish Ecology and Conservation Physiology Laboratory, and ${ }^{2}$ Insect Flight Group, Department of Biology, \\ Carleton University, 1125 Colonel By Drive, Ottawa, Ontario K1S 5B6, Canada \\ ${ }^{3}$ Ministère des Ressources naturelles et de la Faune, 201 Place Charles Le Moyne, 4e étage, bureau 4.05, Longueuil, Québec \\ J4K 2T5, Canada \\ ${ }^{4}$ Katopodis Ecohydraulics Ltd., 122 Valence Avenue, Winnipeg, Manitoba R3T 3W7, Canada \\ ${ }^{5}$ Water Resources Engineering, University of Alberta, 3-032 Markin/CNRL Natural Resources, Edmonton, Alberta T6G 2W2, Canada \\ ${ }^{6}$ Institute of Environmental Science, Carleton University, 1125 Colonel By Drive, Ottawa, Ontario K1S 5B6, Canada
}

\begin{abstract}
Spawning migrations of sturgeon have been affected by the construction of dams, which create barriers to migration and have contributed to the imperilment of sturgeon. Although devices have been installed to facilitate the upstream passage of fish at barriers, they have been generally unsuccessful and not designed for sturgeon. We examined fine-scale movements of adult lake sturgeon Acipenser fulvescens during passage through a vertical slot fishway located on the Richelieu River in Quebec, Canada, to determine passage success, passage duration and inter-individual differences in fishway use. Migratory lake sturgeon $(\mathrm{n}=107$, range 939 to $1625 \mathrm{~mm}$ total length [TL]) were captured immediately downstream of the fishway, tagged with passive integrated transponder (PIT) tags and released into the fishway entrance basin over a period of $2 \mathrm{wk}$ (water temperature $11-20^{\circ} \mathrm{C}$ ). An array of 16 PIT antennas acted as gates to enable quantification of movements within the fishway. Volitional entry into the fishway occurred for most individuals $(82.2 \%), 32$ individuals successfully ascended the entire fishway, and overall passage efficiency was $36.4 \%$. Sturgeon exhibited an ability to traverse the fishway quickly (minimum duration of $1.2 \mathrm{~h}$ upon entry into the fishway); however, the duration of successful passage events was variable $(6.2-75.4 \mathrm{~h}$ following release). Neither passage duration nor maximum distance of ascent was correlated with TL or water temperature. Passage behaviour was variable, in some cases resulting in cumulative upstream movements 3 times in excess of fishway length. Passage durations through the 2 turning basins were disproportionately longer compared with other basins; however, the activity of individuals within these and other locations remains unknown and represents an important knowledge gap. Collectively, data from this study contribute to understanding how fishways can be used to facilitate the upstream passage of imperilled sturgeon at dams.
\end{abstract}

KEY WORDS: Acipenseridae $\cdot$ Sturgeon $\cdot$ Fishway $\cdot$ Fish passage $\cdot$ Migration $\cdot$ PIT

\section{INTRODUCTION}

The construction of dams on large rivers, primarily for hydropower and flood control, has resulted in fragmentation of riverine habitats throughout the world, with estimates in excess of 45000 large dams
(Nilsson et al. 2005). This disconnection has resulted in a loss of key migratory pathways for numerous fish species, often reflected by population declines (e.g. Sheer \& Steel 2006) or genetic isolation (e.g. Jager et al. 2001). Artificial barriers to movement are therefore regarded as a threat to many fish populations 
worldwide (e.g. Rochard et al. 1990), with the construction and subsequent evaluation of fish passage facilities, collectively referred to as 'fishways', representing a growing field of research (Katopodis 2005, Roscoe \& Hinch 2010).

Fishways commonly prevent or delay passage for many species (Roscoe \& Hinch 2010). In some instances, passage failure can result from poor attraction, which can potentially be improved by altering attraction flows and/or modifying the entrance to the fish passage facility (e.g. Bunt 2001, Laine et al. 2002). In other cases, fish are able to locate a fishway, but are unable or unwilling to ascend the device (Katopodis 2005). Passage failure can be a result of inappropriate behavioural decisions (e.g. Hinch \& Bratty 2000), physiological condition (e.g. Pon et al. 2009) or swimming capacity (e.g. Peake et al. 1997). In many cases, the mechanistic causes of failure remain unknown.

Frequently, fishway design and operation targets just a few species, and the needs of other species may not be met (Katopodis 2005, Mallen-Cooper \& Brand 2007, Parsley et al. 2007). Unsuccessful fishway passage remains a particular concern for sturgeons, as passage is rare (Parsley et al. 2007) and limits population recovery for numerous species (Rochard et al. 1990). Sturgeons are unique, long-lived organisms of the Acipenseridae family that comprise 27 living species spanning the temperate zones of Europe, Asia and North America (Bemis \& Kynard 1997). Historically an important food source, exploitation and habitat modification have placed the majority of species under threat of extinction throughout their broad geographic range (Rochard et al. 1990, Birstein 1993). Sturgeons exhibit a variety of life history strategies throughout their distribution, with adults of some species remaining at sea for much of their life, whilst others are confined solely to freshwater (Rochard et al. 1990, Bemis \& Kynard 1997). All species share a common strategy, migrating up predominantly large rivers to spawn (Bemis \& Kynard 1997). Subsequently, barriers that block the passage of migratory pathways are recognised as a key threat to all sturgeon species and have been implicated in their global imperilment (Rochard et al. 1990). This is of particular concern because sturgeons represent 1 of the world's most threatened groups of animals, with 16 species currently listed as Critically Endangered and 2 species as Endangered (IUCN 2010).

Quantitative information on sturgeon use of fishways in the field is limited to a single peer-reviewed study (Parsley et al. 2007), with the majority of information derived from either laboratory simulations of fishways (Cheong et al. 2006, Webber et al. 2007) or extrapolated from swimming performance in a flume (Peake et al. 1997). While sturgeons have been documented entering fishways designed for other species, a large proportion of fish are either unwilling or unable to ascend, and thus, successful upstream passage is rarely documented (Parsley et al. 2007). Successful negotiation of simulated fishways in flumes by sturgeon suggests that passage speed increases with decreased turbulence and increased velocity; however, passage efficiency in flumes can still be relatively poor (Cheong et al. 2006). Further, sturgeon exhibit different behavioural responses during passage, bursting through high velocity areas and resting in low velocity areas (Webber et al. 2007), presumably in response to their quick fatigue times (Peake et al. 1997). Captive sturgeons also respond to high flows in flumes by stationing themselves on the benthos (e.g. Adams et al. 2003), a presumed energyconserving behaviour that has also been documented in the field in response to hydro peaking flows (Geist et al. 2005). Successful fishway passage by sturgeon is expected to be determined by a combination of favourable hydraulic conditions, water temperature and fish size (Peake et al. 1997). To date, attempt rate, passage duration and behaviour of upstream migrating sturgeons have not been quantified within fishways in a field setting.

We used locally abundant lake sturgeon Acipenser fulvescens as a model species to identify the frequency of different behaviours exhibited during fishway ascension at a vertical slot fishway in Quebec, Canada. Nationally, the Committee on the Status of Endangered Wildlife in Canada (COSEWIC) has listed lake sturgeon populations as being of special concern, threatened or endangered depending on the population (www.cosewic.gc.ca/eng/sct1/Search Result_e.cfm?commonName=Lake+sturgeon\&science Name=\&Submit=Submit). Given the annual spawning migrations of this species, a barrier-free 250 to $300 \mathrm{~km}$ combined river and lake range has been suggested as a minimum distance to support self-sustaining lake sturgeon populations (Auer 1996). The installation of fishways is currently used as a remedial management tool when a barrier blocks access to upstream spawning locations and cannot be removed; however, success is rarely known. For this study, we aimed to compare passage duration and behavioural differences between successful and unsuccessful migrant lake sturgeon at a vertical slot fishway, and identify any areas of difficult passage. We tested the following hypotheses: (1) behavioural differences exist between successful and unsuccess- 
ful migrants, (2) passage duration is not uniform throughout the fishway, and (3) passage success is influenced by fish size and water temperature. Data from this study have the potential to be used to enhance fish passage success for lake sturgeon and other confamilials throughout their range.

\section{MATERIALS AND METHODS}

\section{Study site}

This study was conducted at the VianneyLegendre Fishway, a vertical slot fishway located on the Richelieu River adjacent to the St. Ours dam in southwestern Quebec, Canada (Fig. 1). The Richelieu River originates in Vermont and New York, USA, and, after exiting Lake Champlain, empties into the St. Lawrence River near the town of Sorel, Quebec, Canada. The river is $124 \mathrm{~km}$ long, and its average annual discharge is $362 \mathrm{~m}^{3} \mathrm{~s}^{-1}$. The St. Ours dam is located $18 \mathrm{~km}$ upstream of the confluence between the Richelieu and St. Lawrence Rivers and comprises a $180 \mathrm{~m}$ wide, $3.4 \mathrm{~m}$ high structure divided into a series of 5 submersible gates (each $30 \mathrm{~m}$ wide, plus the fishway). Its main function is to maintain a stable

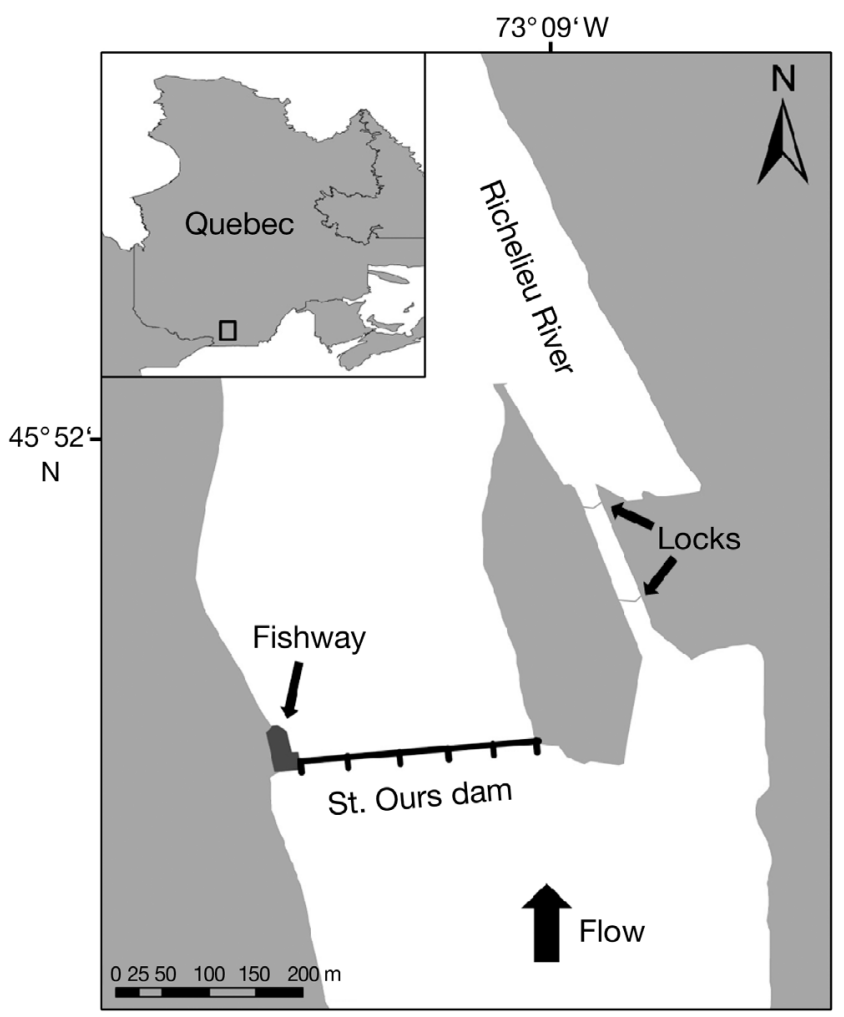

Fig. 1. Location of the Vianney-Legendre vertical slot fishway on the Richelieu River, Quebec, Canada water level upstream for navigation purposes. The fishway was constructed on the west bank of the dam in 2001 to provide upstream access for key migratory species including lake sturgeon, copper redhorse Moxostoma hubbsi, river redhorse $M$. carinatum, American shad Alosa sapidissima and American eel Anguilla rostrata. The total number of fish ascending the fishway is not known; however, monitoring since 2001 during May and June in each year indicates that the fishway passes more than 35 species of fish. Between 5 and 52 lake sturgeon use the fishway each year to access upstream spawning areas (P. Dumont unpubl. data).

The fishway is an $85 \mathrm{~m}$ long concrete structure which rises $2.65 \mathrm{~m}$ and includes large entrance and exit basins on small slopes. The rest of fishway is divided into 12 uniform rectangular basins $(3.5 \times$ $3.0 \mathrm{~m})$ connected by 2 resting/turning basins with horizontal floors and curved walls $(2.75 \mathrm{~m}$ radius; Fig. 2). The uniform basins have successive floor drops of $0.15 \mathrm{~m}$, for a total rise of $2.4 \mathrm{~m}$, and are each separated by a $0.6 \mathrm{~m}$ wide vertical slot ( 2.3 to $4.0 \mathrm{~m}$ height range). This vertical slot width, $b_{0}=0.6 \mathrm{~m}$, and uniform basin size $\left(5.8 b_{0} \times 5 b_{0}\right)$ is smaller compared to standard designs of $10 b_{0}$ length by $8 b_{0}$ width (Rajaratnam et al. 1992) and results in a relatively larger velocity variation between the basins and a different velocity pattern inside each basin (see Liu et al. 2006). Originally rock and cobble substrate was placed throughout the bottom of the fishway. This substrate has since redistributed and has predominantly accumulated in the turning basins. Migrating fish are required to swim a minimum of $14.8 \mathrm{~m}$ through the entrance basin and an additional $70.5 \mathrm{~m}$ after encountering the first vertical slot in order to successfully pass. The fishway passes approximately $1 \mathrm{~m}^{3} \mathrm{~s}^{-1}$ of water, with a capacity for an additional $6.5 \mathrm{~m}^{3} \mathrm{~s}^{-1}$ attraction flow near the entrance basin via a pass-through chamber beneath the fishway. However, attraction flow was not used in this study given that fish were introduced into the first basin and the focus of the study was not on attraction efficiency (i.e.

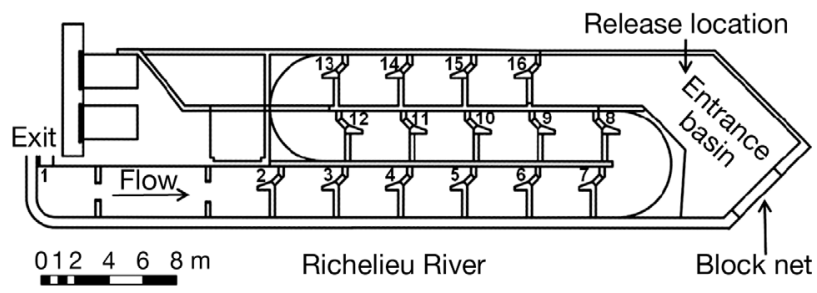

Fig. 2. Schematic of the Vianney-Legendre fishway, with numbers indicating PIT antenna locations used to determine sturgeon movement, behaviour and passage success 
the proportion of released individuals attracted to the fishway; Bunt et al. 1999). An estimate of the velocity at the vertical slot can be made using a water surface drop being the same as the successive floor drop $(\Delta \mathrm{h}=0.15 \mathrm{~m})$, which results in a predicted velocity of $(2 g \Delta \mathrm{h})^{1 / 2}$ or $1.72 \mathrm{~m} \mathrm{~s}^{-1}$, where $g$ is gravitational acceleration $\left(9.81 \mathrm{~m} \mathrm{~s}^{-2}\right)$. During the study, water velocity measurements were collected at 20,60 and $80 \%$ of total depth at each vertical slot (Marsh-McBirney flow mate, model 2000). Velocity approached predicted values at upstream locations (e.g. $1.65 \pm$ $0.02 \mathrm{~m} \mathrm{~s}^{-1}$ averaged across all depths at the most upstream vertical slot; Fig. 2); however, velocity was considerably lower at extreme downstream locations (e.g. $1.11 \pm 0.02 \mathrm{~m} \mathrm{~s}^{-1}$ averaged across all depths at the most downstream vertical slot; Fig. 2) due to elevated tailwater associated with blocking the fishway entrance (see next section). Overall average water velocity for all vertical slots and depths was $1.40 \pm$ $0.01 \mathrm{~m} \mathrm{~s}^{-1}$. We were unable to manipulate flows within the fishway due to its fixed slope. Attempts to vary vertical slot water velocities by manipulating the (upstream) exit gate height were limited due to the placement of an antenna at the exit gate; subsequently, flow was not used as a covariate in any analysis.

\section{Experimental design}

A passive integrated transponder (PIT) array consisting of 16 antennas (beginning at antenna 16 downstream and ending at antenna 1 upstream; see Fig. 2) was installed within the fishway during a dewatering period in early May. This method is suited for use within fishways as fish are required to swim through known locations, and has previously been used with high success (see Castro-Santos et al. 1996 for an overview). Complete pass-through antennas were attached to the upstream-facing side of each vertical slot baffle $(n=15)$ and consisted of 12-gauge stranded electrical wire fixed in place at each corner to create a rectangular shape of $0.65 \mathrm{~m}$ width and varying height (2.2 to $3.2 \mathrm{~m})$ depending upon vertical slot dimensions. An additional passthrough antenna was installed on the upstream exit gate. A minimum distance of $5 \mathrm{~cm}$ was maintained between antennas and concrete walls/metal baffles to maximise detection efficiency. Each antenna was connected to a remote tuner box (Oregon RFID), each of which was connected in groups of 4 via twin-axial cable to a multiplexor unit (Oregon RFID). Antennas were manually tuned during operational water levels to maximise detection range $(\sim 0.5 \mathrm{~m})$ and performance. Multiplexors were programmed to sequentially scan at high speed through all 4 antenna channels and upon positive detection store a unique tag identification number, antenna number and date and time stamp. Detection efficiency of individual antennas during the study was $86.2 \pm 2.4 \%$ (range $68.8-97.5 \%$ ) and was calculated as the number of antennas that individuals were known to have encountered compared with the number of antennas on which individuals were detected (Castro-Santos et al. 1996).

Lake sturgeon $(\mathrm{n}=107$, mean $\pm \mathrm{SE}$ total length, $\mathrm{TL}$, and weight: $1213 \pm 14 \mathrm{~mm}$ and $10.4 \pm 0.4 \mathrm{~kg}$ ) were captured (11 to 25 May 2010) in the first $700 \mathrm{~m}$ downstream of the fishway using 20.3, 25.4 and $30.5 \mathrm{~cm}$ (stretched mesh) gillnets, which were checked twice daily at 09:00 and 15:00 h. The same method is used by government agencies during the spring period for routine lake sturgeon monitoring, and the fish are robust to the stress associated with capture (Baker et al. 2008). Captured sturgeon were immediately transferred to on-site holding facilities and measured, weighed and tagged with a uniquely coded PIT tag $(32 \times 3.85$ mm HDX, Texas Instruments $)$ which was intra-muscularly implanted into the abdominal wall. Tags were inserted using a 6-gauge needle, and surgical wounds were sealed with cyanoacrylate. The entire handling process took less than 2 min, and care was taken to minimise air exposure. Anaesthetics were not used. We also attempted to assign sex to each individual based on the expulsion of gametes; however, we were only successful in determining the sex of 28 individuals comprising 27 males and 1 female, all of which were in pre-spawn condition.

Sturgeon were held indoors immediately adjacent to the fishway in $2250 \mathrm{l}$ flow-through hatchery tanks (with water pumped directly from the river replaced at a rate of $\mathrm{ca} .50 \mathrm{l} \mathrm{min}^{-1}$ ) at a density of no more than $20 \mathrm{~kg}$ per $1000 \mathrm{l}$ for 1 to $3 \mathrm{~d}$ prior to release. There was no mortality associated with capture, handling or holding, and fish were not fed during holding. Sturgeon were released (13-26 May 2010, 12:00-19:00 h) in 5 groups (Trials $1-5$; Table 1) into the entrance basin of the fishway to minimise holding times and to provide potential for passage over a range of water temperatures. There was no significant difference in TL among release groups (1-way analysis of variance, ANOVA: $\left.F_{4,102}=0.854, \mathrm{p}=0.494\right)$. Prior to release, a block net was added to the entrance (downstream) gate to ensure that fishway exit only occurred upon successful passage. Sturgeon were 
Table 1. Acipenser fulvescens. Summary information for PIT-tagged lake sturgeon released into the Vianney-Legendre vertical slot fishway. TL: total length

\begin{tabular}{|ccccccc|}
\hline Trial & $\mathrm{n}$ & $\begin{array}{c}\mathrm{TL} \\
(\mathrm{mm})\end{array}$ & $\begin{array}{c}\text { Water } \\
\text { temperature } \\
\left( \pm \mathrm{SE},{ }^{\circ} \mathrm{C}\right)\end{array}$ & $\begin{array}{c}\text { Trial } \\
\text { duration } \\
(\mathrm{h})\end{array}$ & $\begin{array}{c}\text { No. } \\
\text { successfully } \\
\text { passed }\end{array}$ & $\begin{array}{c}\text { Passage } \\
\text { efficiency } \\
(\%)\end{array}$ \\
\hline 1 & 22 & $1033-1505$ & $11.9 \pm 0.3$ & 72 & 4 & 36.4 \\
2 & 34 & $984-1558$ & $12.2 \pm 0.1$ & 40 & 11 & 36.7 \\
3 & 21 & $990-1625$ & $14.5 \pm 0.1$ & 72 & 9 & 47.4 \\
4 & 19 & $939-1375$ & $17.1 \pm 0.1$ & 86 & 5 & 29.4 \\
5 & 11 & $982-1445$ & $19.8 \pm 0.0$ & 72 & 3 & 27.3 \\
\hline
\end{tabular}

allowed 40 to $86 \mathrm{~h}$ to volitionally enter and pass the fishway, after which the entrance gate was lowered and the remaining sturgeon were flushed from the fishway through a slow dewatering process. One trial was shortened $(40 \mathrm{~h})$ due to an operational problem with the fishway. Water quality values were recorded daily during the study (YSI model 556 water quality meter, Yellow Springs) and were as follows: conductivity $135.33 \pm 1.98 \mu \mathrm{S} \mathrm{cm}^{-1}, \mathrm{pH} 6.69 \pm 0.11$ and dissolved oxygen $10.78 \pm 0.33 \mathrm{mg} \mathrm{l}^{-1}$. In addition, hourly water temperature was recorded in the fishway at the downstream entrance basin at $1 \mathrm{~m}$ depth (DS1921Z iButton, Maxim integrated products).

\section{Data analysis}

Antenna locations were converted to distance metrics beginning at the first antenna (antenna 16, $0 \mathrm{~m}$ ) and ending at the fishway exit (antenna 1,70.5 m), enabling calculation of minimum distances moved throughout the fishway for each sturgeon, as well as the maximum upstream distance of ascent. As only 16 fish (of the 107) were detected by the most downstream antenna and could not be confirmed to have actually entered the fishway (a minimum of 2 antennas are required to determine direction), and 3 fish (of the 107) were not detected by any antennas, all subsequent analyses were conducted on the remaining 88 sturgeon. Sturgeon movements through the fishway were reconstructed over time, and individuals were grouped into behavioural categories based on evidence of single or multiple attempts at passage. A passage attempt was defined as any movement into the fishway (to at least the second antenna, viz. antenna 15, encountered) and terminated upon either successful passage or return to the downstream staging area.

Passage efficiency was calculated as the proportion of successful fishway passage events compared to the number of fish attempting to pass, both for each trial and overall. Size (TL) was compared across the whole sample, between successful and unsuccessful individuals, using an independent samples $t$-test. Log-rank survival analysis was used to test whether the maximum distance of ascent achieved by individuals differed between trials, given that data censoring precludes ordinary least squares techniques (Hosmer \& Lemeshow 1999), and was then plotted for the entire study using a Kaplan-Meier survival estimate. Pearson product moment correlations (or non-parametric Spearman rank equivalents) were used to determine relationships between either water temperature or TL and passage speed and maximum upstream distance. Mean water temperature for each trial was used in the analysis given that within-trial variation was minimal (Table 1). Lag was determined as the time elapsed from release until first entrance into the fishway. A Wilcoxon rank sum test was used to determine whether fish entering the fishway earlier (shorter lag) were more likely to succeed, and a Spearman rank correlation was used to determine the relationship between lag and maximum distance of ascent. All statistical analyses were deemed significant at $\mathrm{p}<0.05$ and conducted using JMP statistical software (version 8.0, SAS Institute). All data were first examined for normality and/or homogeneity of variance where appropriate, transformed (log) and reassessed if they did not meet these assumptions, and analysed using non-parametric equivalents where necessary. All data are presented as means $\pm \mathrm{SE}$, unless otherwise stated.

\section{RESULTS}

Attempts to pass the fishway were made by $82.2 \%$ (88 of 107) of sturgeon in this study. The remaining individuals either made no attempt to enter the fishway $(2.8 \%, \mathrm{n}=3)$ or were only recorded on the most downstream antenna $(15 \%, \mathrm{n}=16)$. Given the detection range $(\sim 0.5 \mathrm{~m})$ of the equipment used, we were unable to distinguish between fish entering the fishway and those simply probing the entrance (in some cases on multiple occasions). Successful fishway ascension occurred for $29.9 \%(n=32)$ of sturgeon released into the fishway, and overall passage efficiency (the proportion of sturgeon entering the fishway [n $=88$ ] compared to the proportion succeeding [ $\mathrm{n}=32$ ]) was $36.4 \%$ (range $27.3-47.4 \%$ among trials; 
Table 1). We found no difference between TL of sturgeon successfully passing the fishway (1232 \pm $25 \mathrm{~mm} ; \mathrm{n}=32$ ) and those entering but failing to pass $(1203 \pm 19 \mathrm{~mm} ; \mathrm{n}=56$; independent samples $t$-test, $t=0.921, \mathrm{p}=0.360)$. There was also no difference between TL of sturgeon failing to enter the fishway $(1209 \pm 34 \mathrm{~mm} ; \mathrm{n}=19)$ and those successfully passing (independent samples $t$-test, $t=-0.547, \mathrm{p}=0.587$ ).

Passage behaviours exhibited by sturgeon were broadly grouped into single attempts (represented by both failure and success, Fig. 3a,c) and multiple attempts (represented by both failure and success, Fig. 3b,d). Sturgeon exhibiting a single attempt and failing characteristically moved short distances upstream (cumulative upstream distance, $14.3 \pm$ $4.3 \mathrm{~m}$ ) in comparison to multiple attempt failures (70.1 $\pm 7.4 \mathrm{~m}$; Table 2). Sturgeon requiring multiple attempts to pass the fishway before succeeding swam an average of $49.1 \mathrm{~m}$ farther upstream (136.1 \pm $12.9 \mathrm{~m}$ ) in comparison to individuals which passed the fishway on their first attempt $(87.0 \pm 4.8 \mathrm{~m}$;
Table 2). The maximum upstream location of the fishway reached by sturgeon did not differ between trials (log-rank survival analysis: $\chi^{2}=1.119$, df $=4$, $\mathrm{p}=0.891$ ), nor was it correlated with TL (Spearman correlation: $r_{\mathrm{s}}=0.059, \mathrm{p}=0.588$ ) or water temperature (Spearman correlation: $r_{s}=-0.052, p=0.632$ ).

Table 2. Acipenser fulvescens. Behavioural characteristics exhibited by lake sturgeon during upstream passage through a vertical slot fishway. Values shown are the cumulative upstream distance $(\mathrm{m})$ that fish swam

\begin{tabular}{|lccc|}
\hline Attempts & $\mathrm{n}$ & Mean $\pm \mathrm{SE}$ & Range \\
\hline Unsuccessful passage & & & \\
No attempt & 3 & & \\
Probe & 16 & & \\
Single attempt & 10 & $14.3 \pm 4.3$ & $3.9-43.7$ \\
Multiple attempts & 46 & $70.1 \pm 7.4$ & $11.7-194.3$ \\
Successful passage & & & \\
Single attempt & 16 & $87.0 \pm 4.8$ & $70.5-139.2$ \\
Multiple attempts & 16 & $136.1 \pm 12.9$ & $74.4-222.7$ \\
\hline
\end{tabular}
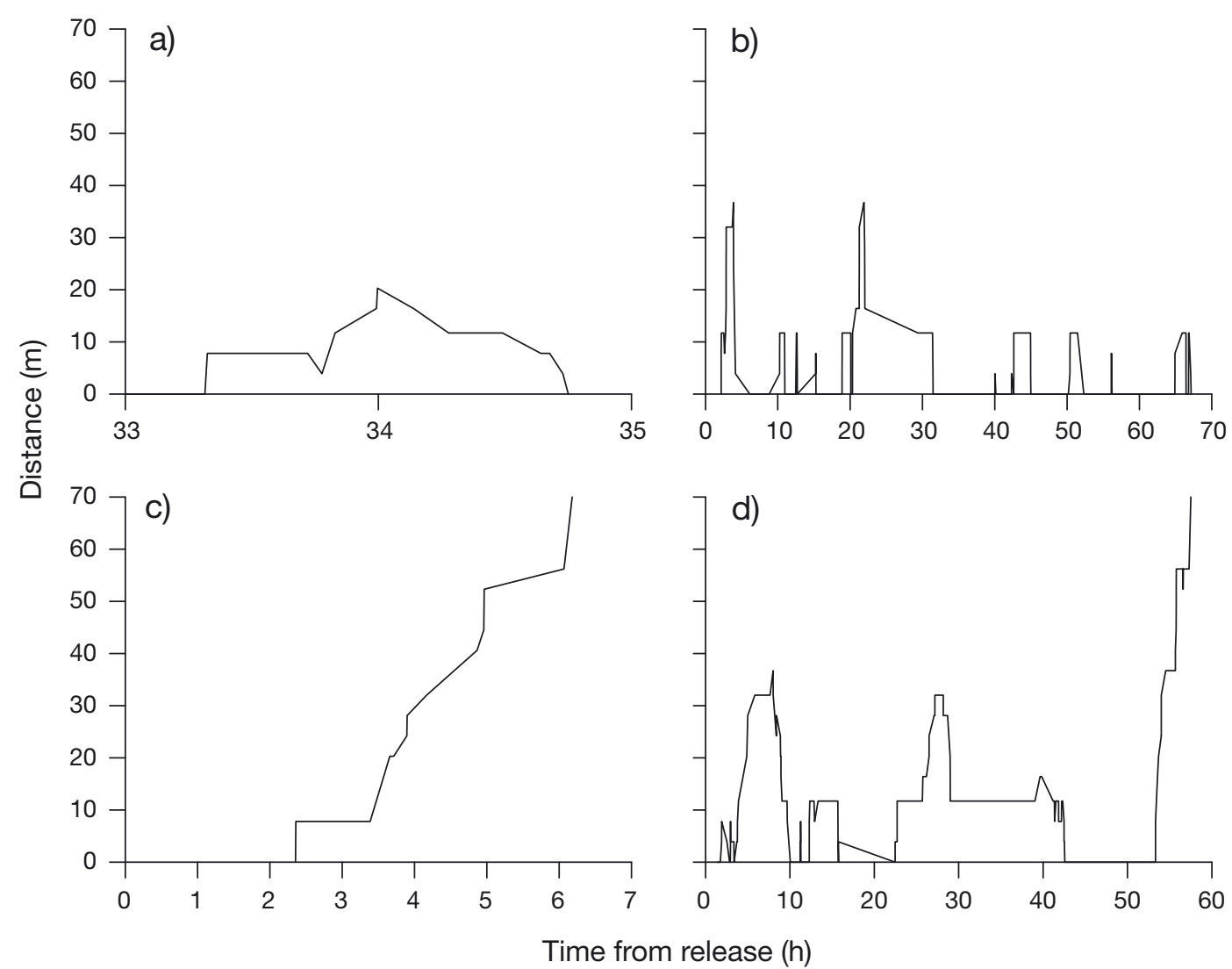

Fig. 3. Acipenser fulvescens. Examples of individual movements exhibited by lake sturgeon during passage through a vertical slot fishway representing (a) a single attempt and failure $\left(1207 \mathrm{~mm}\right.$ total length, $\left.\mathrm{TL}, 12.2^{\circ} \mathrm{C}\right)$, (b) multiple attempts and failure $\left(1218 \mathrm{~mm} \mathrm{TL}, 19.8^{\circ} \mathrm{C}\right)$, (c) single attempt and pass $\left(1266 \mathrm{~mm} \mathrm{TL}, 19.8^{\circ} \mathrm{C}\right)$, and (d) multiple attempts and pass $(1312 \mathrm{~mm}$ $\mathrm{TL}, 19.8^{\circ} \mathrm{C}$ ). Entrance into the fishway occurs at distance $0 \mathrm{~m}$, and fishway exit occurs at distance $70.5 \mathrm{~m}$. Note different $x$-axis scales 
Generally, passage failure was most likely to occur in the downstream half of the fishway $(52.3 \%)$, with failure uncommon (11.4\%) beyond this point (Fig. 3). Fourteen individuals $(15.9 \%)$ reached, but failed to pass, the first turning basin (11.7 $\mathrm{m}$ into the fishway; Fig. 4), representing the location with the single greatest loss.

Although fishway passage occurred throughout the day, it was primarily undertaken during crepuscular or nocturnal periods (Fig. 5). Successful individuals required between 6.19 and $75.38 \mathrm{~h}$ (median $27.38 \mathrm{~h}$ ) to pass the fishway following release. Upon initiation of a successful attempt, passage duration ranged between 1.16 and $30.75 \mathrm{~h}$ (median $3.17 \mathrm{~h}$ ). Passage duration (log transformed) was not significantly correlated with TL, either from release (Pearson product moment correlation: $r_{p}=-0.266, p=$ 0.228 ) or from initiation of a successful attempt (Pearson product moment correlation: $r_{p}=-0.059, p=$ 0.798). Passage duration was not significantly correlated with water temperature, either from release (Spearman correlation: $\mathrm{r}_{\mathrm{s}}=-0.388, \mathrm{p}=0.074$ ) or from initiation of a successful attempt (Spearman correlation: $r_{s}=0.160, p=0.489$ ). No motivational differences were evident between successful and unsuccessful passage events. Time from release until first entrance into the fishway (lag) ranged from 0.03 to $30.28 \mathrm{~h}$ (median $2.66 \mathrm{~h}$ ) and was not significantly different between successful or unsuccessful individu-

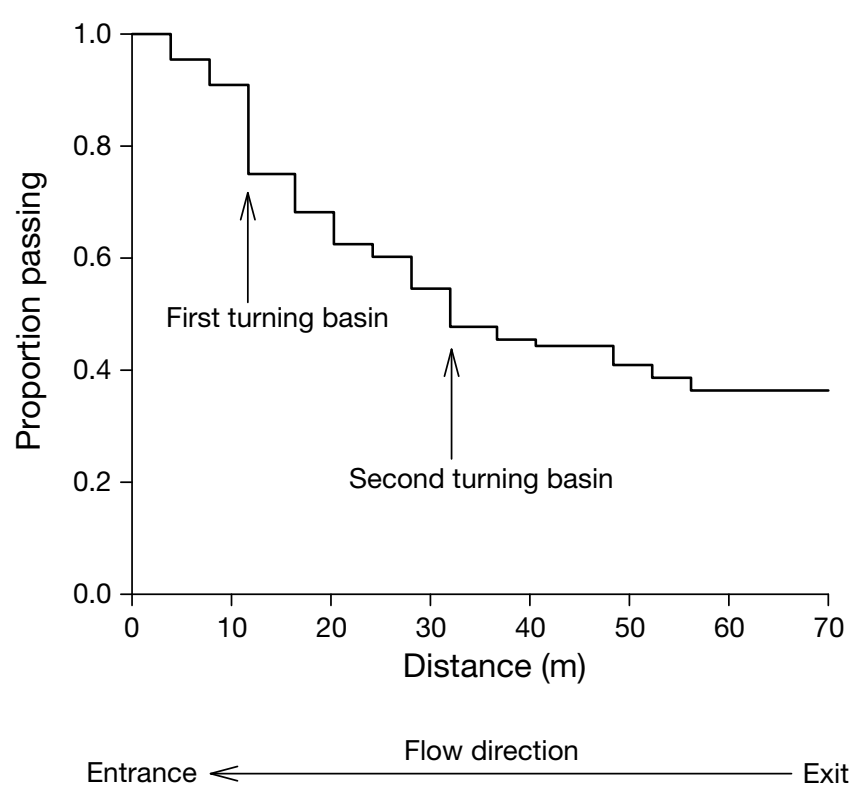

Fig. 4. Acipenser fulvescens. Maximum upstream distance achieved by lake sturgeon attempting to pass the VianneyLegendre vertical slot fishway determined using KaplanMeier survival analysis $(\mathrm{n}=88)$

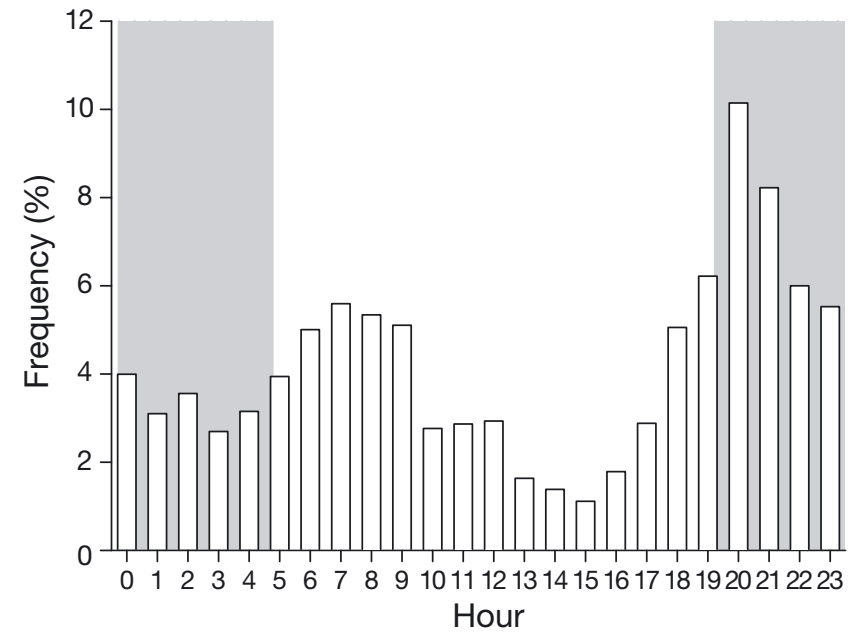

Fig. 5. Acipenser fulvescens. Frequency of PIT records differentiated by time of day from tagged lake sturgeon using the Vianney-Legendre vertical slot fishway. Grey bars indicate night periods based on local sunrise and sunset times

als (Wilcoxon Rank Sum test: $z=-0.358, p=0.721$ ) or correlated with maximum distance of ascent (Spearman correlation: $r_{s}=-0.094, p=0.547$ ).

Passage duration through different basins within the fishway was not uniform. Sturgeon took longer to pass through turning basins (PIT antenna locations 13-12 and 8-7) than through other basins during both unsuccessful (Fig. 6a) and successful passage events (Fig. 6b). In addition, sturgeon took longer to pass from basin 2 to 1 (last vertical slot to the exit; Fig. 2) in comparison to other basins (turning basins notwithstanding; Fig. 6b) during successful passage; however, it should be noted that this distance is 3 times greater than turning basins and 3.6 times greater than through remaining basins.

\section{DISCUSSION}

Globally, sturgeon passage through fishways is poorly understood, despite acknowledgement that barriers to migration are a concern for all species (e.g. Rochard et al. 1990). In this study, we documented a passage efficiency of lake sturgeon in the Vianney-Legendre fishway of $36.4 \%$. This is comparable with the only other passage efficiency estimate that we located in a peer-reviewed study. Parsley et al. (2007) reported a passage estimate of $41.2 \%$ (7 of 17 sturgeon that entered the fishway passed) for white sturgeon Acipenser transmontanus at 2 fishways, which were designed for Pacific salmon, on The Dalles Dam on the Columbia River. The study of Parsley et al. (2007) more likely represents a true 


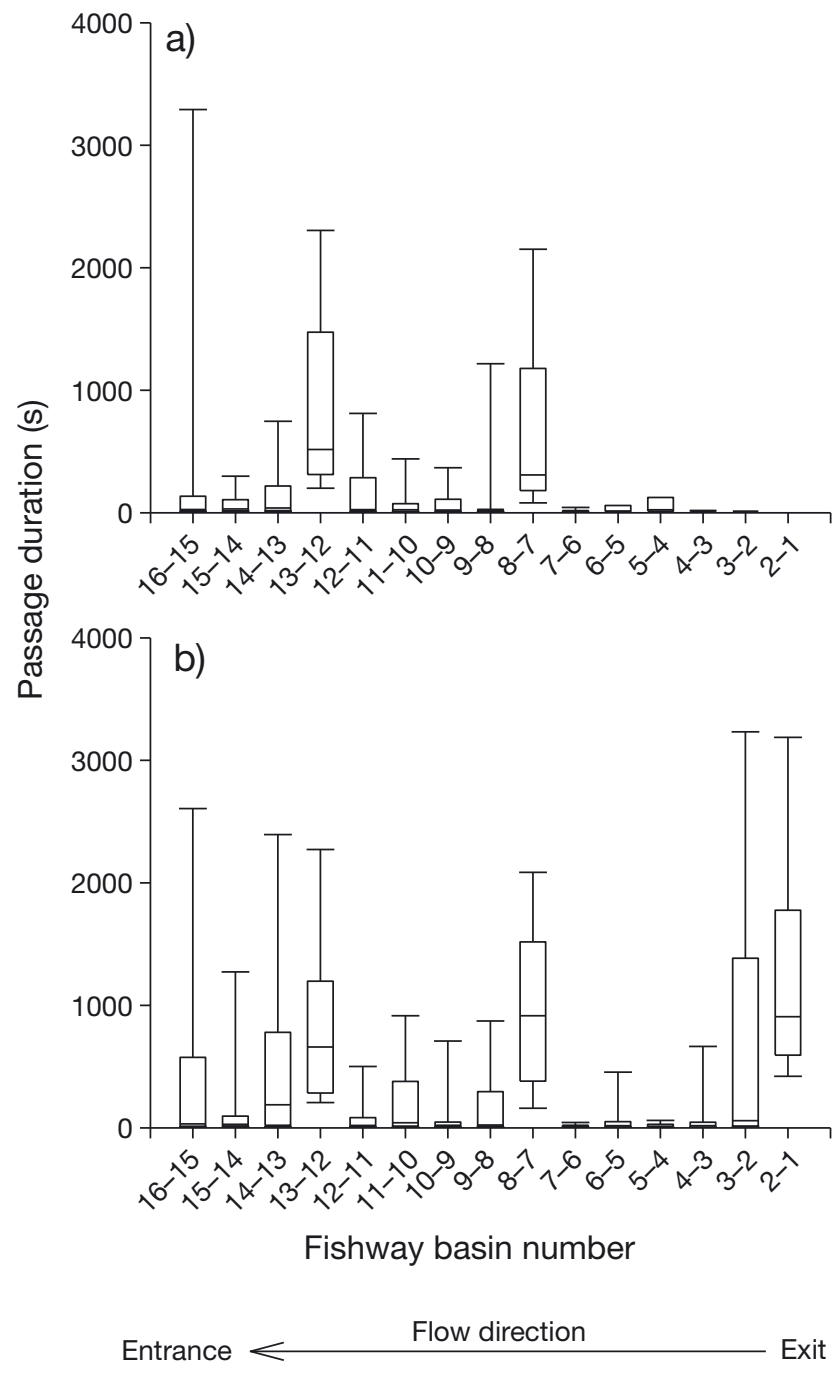

Fig. 6. Acipenser fulvescens. Duration of passage through different locations during upstream movement by lake sturgeon through a vertical slot fishway for (a) unsuccessful individuals $(\mathrm{n}=56)$ and $(\mathrm{b})$ successful individuals $(\mathrm{n}=32)$. Boxes represent 25th and 75th percentiles with the median enclosed within, and whiskers represent 10th and 90th percentiles. Numbers on the $x$-axis refer to consecutive antenna locations (see Fig. 2). Note 13-12 and 8-7 are turning basins, and the distance from 2 to $1(14.25 \mathrm{~m})$ is much greater than between regular basins $(3.9 \mathrm{~m})$

estimate of fishway success, given that sturgeon were attracted to and volitionally entered fishways over a 2 yr period. In our study, fish were captured downstream and introduced into the fishway to enable an experimental evaluation of passage success. Capture stress and potential differences in motivation could have led to low passage success, while confining fish to the fishway could have led to elevated success. Direct comparisons are also cau- tioned, given that the fishways on The Dalles Dam are $>500 \mathrm{~m}$ in length and are pool and weir type with submerged orifices, as opposed to the $70 \mathrm{~m}$ long, vertical slot fishway used in the current study. Given greater fishway length, a similar study design and fishway conditions, we would expect that passage efficiency may be significantly lower than the estimate generated using this experimental approach.

Our study design enabled identification of finerscale passage behaviour than previously reported in most fishway studies. Specifically, we identified that passage failure most commonly occurred in the lower (downstream) portion of the fishway and also that the first turning basin presented an obstacle to passage for 14 of the 88 sturgeon that entered the fishway. The usefulness of turning or resting pools in fishways has been questioned for other species (e.g. walleye Sander vitreus, Bunt et al. 2000; bony herring Nematalosa erebi, silver perch Bidyanus bidyanus and golden perch Macquaria ambigua, White et al. 2011). Turning basins were incorporated into the VianneyLegendre fishway to create a more compact design, enabling the fishway entrance to be located near to the barrier in a site where surveys prior to the fishway design indicated higher fish densities. Despite a number of studies examining white sturgeon negotiation of obstacles in flumes (Cheong et al. 2006, Webber et al. 2007), no information currently exists with which to compare these findings.

Successful and unsuccessful attempts by sturgeon were delayed through turns during fishway passage. Given that the first turning basin is encountered $11.7 \mathrm{~m}$ into the fishway, the second $20.3 \mathrm{~m}$ after the first and a mean water velocity (through vertical slots) of $1.4 \mathrm{~m} \mathrm{~s}^{-1}$, it is reasonable to conclude that turning basins are used for resting, particularly given that Peake et al. (1997) estimated that a comparable length of fishway is passable by $120 \mathrm{~cm}$ lake sturgeon at $1.4 \mathrm{~m} \mathrm{~s}^{-1}$ prior to fatigue. Indeed, Webber et al. (2007) recommended that low velocity (0.51 to $0.68 \mathrm{~m} \mathrm{~s}^{-1}$ ) resting areas be incorporated into fishways designed for sturgeon, as white sturgeon used these to recover following bursts through high velocity (up to $2.52 \mathrm{~m} \mathrm{~s}^{-1}$ ) regions in a flume. A trade-off exists, however, in the provision of low-velocity refuges in fishways. For example, both Cheong et al. (2006) and Webber et al. (2007) found white sturgeon more likely to attempt upstream passage when exposed to faster flume velocities. It may be that the creation of flow refuges in turning basins deters fishway passage by some sturgeon due to a lack of motivational cues. Flow refuging and presumably energy 
conservation are achievable by sturgeon in highvelocity areas through benthic station holding (e.g. Adams et al. 2003, Geist et al. 2005), so resting pools may not be a necessary provision in sturgeon fishways.

Lake sturgeon often moved greater cumulative upstream distances than the length of the fishway in the current study, primarily due to multiple attempts at passage resulting in both success and failure. Multiple attempts have also been observed for numerous other species during passage ascension (e.g. Bunt et al. 1999, Castro-Santos 2004), suggesting that this behaviour should be considered when matching fishway design with laboratory swimming capacity (e.g. Peake et al. 1997). However, in some instances swimming performance estimates (e.g. critical swim speed) have no direct relevance beyond the laboratory (Beamish 1978). For example, Peake (2004) found laboratory swimming performance to be a poor indicator of successful passage in smallmouth bass Micropterus dolomieu, as field success was high among all water velocities tested and independent of fish length and water temperature. Similarly, we found no relationship between water temperature or fish length and passage speed, passage success or maximum upstream distance, despite previous work identifying that both of these are important factors influencing lake sturgeon swimming performance in the laboratory (Peake et al. 1997). It may be that for fish to be successful during passage events and maximise their swimming potential, behavioural choices resulting in a switch to the optimal gait when faced with variable hydraulic conditions are required (Castro-Santos 2005). However, Castro-Santos (2005) identified that only 3 of 6 species studied (note that sturgeon were not studied) used an optimal swim mode when traversing a velocity barrier, with the behavioural choices of others resulting in a failure to maximise distance ascended.

Navigational choices that affect time to exhaustion may also explain the inter-individual variation in successful fishway passage exhibited by sturgeon in the current study. For example, Hinch \& Bratty (2000) found that some sockeye salmon Oncorhynchus nerka exhibited hyperactivity which resulted in passage failure, while others probably chose a less difficult route, resulting in reduced energy expenditure and ultimately successful passage. Certainly, swimming in higher turbulence, but at the same velocity, can be more energetically costly and subsequently decrease endurance (Enders et al. 2005). However, a trade-off can occur, where the more turbulent environment may also represent the shortest route, thus minimising migration time when chosen (e.g. Standen et al. 2002). Spatial variation in water velocity, resulting in multiple paths of differing hydraulic conditions being available for fish to move through, certainly exists within vertical slot fishways. For example Wu et al. (1999) observed that in vertical slot fishways, even for fishways with slopes of $5 \%$ or less when flow patterns are relatively simpler than for steeper slopes, the direction and magnitude of water velocity within basins are spatially variable. Path selection as it relates to hydraulic conditions within fishways (i.e. turbulent kinetic energy, Reynold's shear stress; Silva et al. 2011) represents a logical next step to identify favourable hydraulic conditions conducive to sturgeon passage. Further, activity levels of sturgeon during fishway ascension were not assessed in the current study. Use of techniques including acceleration sensors on biologging or biotelemetry devices or visualisation using video or acoustic cameras represent an important next step in identification of activity (and subsequent energy use) at different locations within fishways and may distinguish successful and unsuccessful individuals. Such an approach would also enable one to generate more direct relationships between fine-scale hydraulic conditions and fish behaviour.

Endogenous factors relating to differences in energy stores, stress or motivation (i.e. endocrine/ maturation state) also represent potential explanations for inter-individual variability in passage success, although these factors were not tested in the current study. Stress is unlikely to explain individual differences in behaviour given that all sturgeon were subjected to the same treatment, and previous work by Baker et al. (2008) indicated that both the holding duration ( 1 to $3 \mathrm{~d}$ ) and time allowed for fishway ascension ( 2 to 3 d) are sufficient to allow for recovery from any adverse responses to either handling, capture or tagging techniques for this species at comparable water temperatures. Gross somatic energy density has previously been found to correlate with maximum distance travelled during upstream migrations of Chinook salmon Oncorhynchus tshawytscha (Hasler et al. 2009), although its use to differentiate fishway passage success remains untested. It is possible that motivational differences may explain variation in fishway success among sturgeon, and the measurement of sex steroid levels (e.g. McKinley et al. 1998) to assess this represents a logical next step. 


\section{CONCLUSIONS}

Restoring connectivity of riverine systems that have been fragmented by dams is a critical step towards rebuilding sturgeon populations and preventing extinction (Auer 1996, Jager 2006). Although fishways are regarded as a potential strategy for mitigating the installation of barriers, a range of studies have documented that their efficiency can be highly variable (Roscoe \& Hinch 2010). Given that adult sturgeon tend to migrate upstream to spawn, and that there are few examples of successful fishways for sturgeon, we focused our efforts on a promising vertical slot fishway in Quebec. Using an experimental approach where adult lake sturgeon were released into the bottom pool of the fishway, we were able to generate an estimate of passage success as well as to identify detailed behaviours within the fishway. Of particular concern was the fact that we identified that sturgeon had difficulties passing through turning basins. Such knowledge will be useful in identifying potential means of improving passage of sturgeon in existing and future fishways. If sturgeon populations in rivers with migration barriers are to recover, provisions for effective fish passage are critical. Additional work is needed to identify the biotic, environmental and hydraulic characteristics that influence both attraction and passage efficiency for sturgeon as well as other riverine fish species that are susceptible to habitat fragmentation by dams.

Acknowledgements. F. Archambault, S. Desloges, C. Hatry, J. Leclerc, G. Lemieux, B. McDougall and K. Stamplecoskie provided expert field assistance. Parks Canada (A. Brunelle, J. Larochelle and G. Noël) provided site access. G. McDonald (University of Guelph) and K. Clarke (DFO) kindly lent equipment, and W. Leach (Oregon RFID) provided technical support. Comments from anonymous reviewers improved the manuscript. Project funding was provided by an NSERC HydroNet Strategic Network Grant. Equipment support was provided by the Canada Foundation for Innovation, the Ontario Research Fund and the NSERC RTI program. Significant financial and in-kind contributions were also provided by the Quebec MNRF. S.J.C. was supported by the Canada Research Chair program and J.D.T. was supported by a President's graduate scholarship from Carleton University. This project was conducted in accordance with the guidelines of the Canadian Council on Animal Care administered by the Carleton University Animal Care Committee (B10-12).

\section{LITERATURE CITED}

Adams SR, Adams GL, Parsons GR (2003) Critical swimming speed and behavior of juvenile shovelnose sturgeon and pallid sturgeon. Trans Am Fish Soc 132:392-397
Auer NA (1996) Importance of habitat and migration to sturgeons with emphasis on lake sturgeon. Can J Fish Aquat Sci 53(Suppl 1):152-160

Baker DW, Peake SJ, Kieffer JD (2008) The effect of capture, handling, and tagging on haematological variables in wild adult lake sturgeon. N Am J Fish Manag 28: 296-300

Beamish FWH (1978) Swimming capacity. In: Hoar WS, Randall DJ (eds) Fish physiology, Vol. 7. Academic Press, New York, NY, p 101-172

Bemis W, Kynard B (1997) Sturgeon rivers: an introduction to acipenseriform biogeography and life history. Environ Biol Fishes 48:167-183

Birstein V (1993) Sturgeon and paddlefishes: threatened fishes in need of conservation. Conserv Biol 7:773-782

Bunt CM (2001) Fishway entrance modifications enhance fish attraction. Fish Manag Ecol 8:95-105

Bunt CM, Katopodis C, McKinley RS (1999) Attraction and passage efficiency of white suckers and smallmouth bass by two Denil fishways. N Am J Fish Manag 19:793-803

Bunt CM, Cooke SJ, McKinley RS (2000) Assessment of the Dunnville fishway for passage of walleyes from Lake Erie to the Grand River, Ontario. J Gt Lakes Res 26: $482-488$

Castro-Santos T (2004) Quantifying the combined effects of attempt rate and swimming capacity on passage through velocity barriers. Can J Fish Aquat Sci 61:1602-1615

> Castro-Santos T (2005) Optimal swim speeds for traversing velocity barriers: an analysis of volitional high-speed swimming behavior of migratory fishes. J Exp Biol 208:421-432

Castro-Santos T, Haro A, Walk S (1996) A passive integrated transponder (PIT) tag system for monitoring fishways. Fish Res 28:253-261

> Cheong TS, Kavvas ML, Anderson EK (2006) Evaluation of adult white sturgeon swimming capabilities and applications to fishway design. Environ Biol Fishes 77:197-208

$>$ Enders EC, Boisclair D, Roy AG (2005) A model of total swimming costs in turbulent flow for juvenile Atlantic salmon (Salmo salar). Can J Fish Aquat Sci 62:1079-1089

Geist DR, Brown RS, Cullinan V, Brink SR, Lepla K, Bates P, Chandler JA (2005) Movement, swimming speed, and oxygen consumption of juvenile white sturgeon in response to changing flow, water temperature, and light level in the Snake River, Idaho. Trans Am Fish Soc 134: 803-816

Hasler CT, Pon LB, Roscoe DW, Mossop B, Patterson DA, Hinch SG, Cooke SJ (2009) Expanding the 'toolbox' for studying the biological responses of individual fish to hydropower infrastructure and operating strategies. Environ Rev 17:179-197

Hinch SG, Bratty JM (2000) Effects of swim speed and activity pattern on success of adult sockeye salmon migration through an area of difficult passage. Trans Am Fish Soc 129:598-606

Hosmer DW, Lemeshow S (1999) Applied survival analysis. Wiley, New York, NY

IUCN (International Union for Conservation of Nature) (2010) IUCN Red List of Threatened Species. Available at www.iucnredlist.org (accessed 9 December 2010)

> Jager HI (2006) Chutes and ladders and other games we play with rivers. I. Simulated effects of upstream passage on white sturgeon. Can J Fish Aquat Sci 63:165-175

Jager HI, Chandler JA, Lepla KB, Van Winkle W (2001) A theoretical study of river fragmentation by dams and its 
effects on white sturgeon populations. Environ Biol Fishes 60:347-361

Katopodis C (2005) Developing a toolkit for fish passage, ecological flow management and fish habitat works. J Hydraul Res 43:451-467

Laine A, Jokivirta T, Katopodis C (2002) Atlantic salmon, Salmo salar L., and sea trout, Salmo trutta L., passage in a regulated northern river-fishway efficiency, fish entrance and environmental factors. Fish Manag Ecol 9: 65-77

Liu M, Rajaratnam N, Zhu DZ (2006) Mean flow and turbulence structure in vertical slot fishways. J Hydraul Eng 132:765-777

Mallen-Cooper M, Brand DA (2007) Non-salmonids in a salmonid fishway: What do 50 years of data tell us about past and future fish passage? Fish Manag Ecol 14: 319-332

McKinley S, Van Der Kraak G, Power G (1998) Seasonal migrations and reproductive patterns in the lake sturgeon, Acipenser fulvescens, in the vicinity of hydroelectric stations in northern Ontario. Environ Biol Fishes 51: 245-256

Nilsson C, Reidy CA, Dynesius M, Revenga C (2005) Fragmentation and flow regulation of the world's large river systems. Science 308:405-408

Parsley MJ, Wright CD, van der Leeuw BK, Kofoot EE, Peery CA, Moser ML (2007) White sturgeon (Acipenser transmontanus) passage at the Dalles Dam, Columbia River, USA. J Appl Ichthyol 23:627-635

$>$ Peake S (2004) An evaluation of the use of critical swimming speed for determination of culvert water velocity criteria for smallmouth bass. Trans Am Fish Soc 133:1472-1479

Peake S, Beamish FWH, McKinley RS, Scruton DA, Katopodis C (1997) Relating swimming performance of lake sturgeon, Acipenser fulvescens, to fishway design. Can J Fish Aquat Sci 54:1361-1366

Editorial responsibility: Rory Wilson,

Swansea, UK
Pon LB, Hinch SG, Cooke SJ, Patterson DA, Farrell AP (2009) Physiological, energetic and behavioural correlates of successful fishway passage of adult sockeye salmon Oncorhynchus nerka in the Seton River, British Columbia. J Fish Biol 74:1323-1336

Rajaratnam N, Katopodis C, Solanki S (1992) New designs for vertical slot fishways. Can J Civ Eng 19:402-414

Rochard E, Castelnaud G, LePage M (1990) Sturgeons (Pisces: Acipenseridae); threats and prospects. J Fish Biol 37 (Suppl A):123-132

Roscoe DW, Hinch SG (2010) Effectiveness monitoring of fish passage facilities: historical trends, geographic patterns and future directions. Fish Fish 11:12-33

Sheer MB, Steel EA (2006) Lost watersheds: barriers, aquatic habitat connectivity, and salmon persistence in the Willamette and lower Columbia River basins. Trans Am Fish Soc 135:1654-1669

Silva AT, Santos JM, Ferreira MT, Pinheiro AN, Katopodis C (2011) Effects of water velocity and turbulence on the behaviour of Iberian barbell (Luciobarbus bocagei, Steindachner 1864) in an experimental pool-type fishway. River Res Appl 27:360-373

Standen EM, Hinch SG, Healey MC, Farrell AP (2002) Energetic costs of migration through the Fraser River Canyon, British Columbia, in adult pink (Oncorhynchus gorbuscha) and sockeye (Oncorhynchus nerka) salmon as assessed by EMG telemetry. Can J Fish Aquat Sci 59:1809-1818

> Webber JD, Chun SN, Maccoll TR, Mirise LT and others (2007) Upstream swimming performance of adult white sturgeon: effects of partial baffles and a ramp. Trans Am Fish Soc 136:402-408

- White LJ, Harris JH, Keller RJ (2011) Movement of three non-salmonid fish species through a low-gradient vertical-slot fishway. River Res Appl 27:499-510

> Wu S, Rajaratnam N, Katopodis C (1999) Structure of flow in vertical slot fishway. J Hydraul Eng 125:351-360

Submitted: March 21, 2011; Accepted: June 3, 2011 Proofs received from author(s): September 16, 2011 